\title{
EFFECT OF IRRIGATION WATER AMOUNTS AND NITROGEN RATES, ON CUCUMBER OPTIMUM YIELD AND NET RETURN, UNDER DRIP IRRIGATION AT NORTHWEST DELTA, EGYPT
}

Atia, R. H.; A. S. M. El-Saady and Gh. Sh. El-Atawy

Soils, Water and Environment Res. Inst. Agric. Res. Center, Giza, Egypt

\section{ABSTRACT}

Two field experiments were carried out at Wady Elnatron, El-Behera Governorate, during 2007 and 2008 seasons, to study the effect of irrigation water amounts and nitrogen rates, on cucumber yield and the net return from these treatments, under drip irrigation system. Split-plot design was used with four replicates. The main plots were assigned by four irrigation water amounts $(100 \%$, $90 \%, 80 \%$ and $70 \%$ ) of evapotranspiration (ETc). The sub-plots were randomly assigned by four nitrogen rates $\left(0\right.$ addition $\left(N_{0}\right), 50\left(N_{1}\right), 100\left(N_{2}\right)$ and $150\left(N_{3}\right) \mathrm{kg} \mathrm{N}$ fed. ${ }^{-1}$.) as ammonium nitrate. The other recommended agriculture practices were done.

Four polynomial quadratic equations were established to show the following results:

1. The maximum and optimum $N$ rates $\left(X_{m}\right.$ and $\left.X_{o p t}\right)$ were increased as irrigation water amounts decreased in the two seasons.

2. The maximum and optimum cucumber yields $\left(Y_{m}\right.$ and $\left.Y_{o p t}\right)$ were decreased as irrigation water amounts decreased in the two seasons.

3. The highest maximum yield $\left(23.01\right.$ ton $\left.\mathrm{fed}^{-1}\right),(1$ feddan $=0.42$ hectar $)$, the highest total value of yield (27605 L.E. fed ${ }^{-1}$ ) and the highest return of $\mathrm{N}$ fertilizer (13864 L.E. fed $^{-1}$ ) were obtained as irrigation water amount $100 \%$ of ETc used in the two seasons.

4. The efficiencies of $\mathrm{N}$ rates $(\mathrm{eX})$ were decreased as $\mathrm{N}$ rates increased from $\mathrm{N}_{0}$ to $N_{1}, N_{2}$ and $N_{3}$, respectively, with different irrigation water amounts .

5. The efficiency average $(e \bar{X})$, the relative efficiency $(E X)$ and the efficiency of nitrogen fertilizer at optimum rate $\left(\mathrm{eX}_{\mathrm{opt}}\right)$, were decreased as irrigation water amounts decreased.

6. The soil nitrogen content during plant growth $\left(X_{s}\right)$ was increased as irrigation water amounts decreased.

7. The contribution of soil $\mathrm{N}$ was decreased as irrigation water amounts decreased in the two seasons.

8. The contribution of $\mathrm{N}$ fertilizer was increased as $\mathrm{N}$ levels increased in the two seasons.

Keywords: Cucumber, drip irrigation, $\mathrm{N}$ fertilization, irrigation water amounts, maximum and optimum $\mathrm{N}$ rates.

\section{INTRODUCTION}

Cucumber (Cucumis sativus L.) is the fourth most important vegetable crop after tomato, cabbage and onion as favorite crops in Egypt. It is taken not only for fresh eating but also for salad and pickling (sites from ElAtawy, 2010). It is a primary source of vitamins and minerals in human diet. 
Atia, R. H. et al.

Cucumber can highly be useful for both high and low blood pressure, due to its high content of potassium (50-60 mg/100 g), (Kadans, 1979).

Management of irrigation water is one of the most important factors which influence the yield and quality of crops. It is very useful for high yield and saving both of irrigation water and fertilizer (Knany et al., 2005). BaoZhong et al. (2006) reported that amount of irrigation water significantly affected cucumber plant growth and fruit production.

Fertilizer application is one of the quickest and easiest way of increasing yield per unit area. Nitrogen is considered as one of the major nutrients required for growth, development and yield (Singh et al., 2003, Watcharasak and Thammasak, 2005 and Jilani et al., 2009).

It would be very useful to have adequate information on the probabilities of the various yield outcome that would aid in determine a fertilization program. This would then enable researchers to calculate the economical optimum rate of fertilizer application. The expected yield when this optimum rate is applied, and the obtainable yield at specified rate of fertilizer application can also be predicted (Balba, 1987). Many investigators have used the quantitative approach to evaluate and quantitatively express the response of crops yield to nitrogen fertilizer, Thabet and Balba (1994), El-Shebiny and Badr (1998), Atia ( 2005), Atia et al. ( 2009).

The objectives of the present study were to assess the influence of nitrogen fertilization under different irrigation water amounts on cucumber yield and achieve both the high and optimum net return from the studied treatments.

\section{MATERIALS AND METHODS}

Two field experiments were carried out at Wady Elnatron $\left(30^{\circ} 25^{\prime} \mathrm{N}\right.$ latitude and $30^{\circ} 20^{\prime}$ E longitude), El-Behera Governorate, during 2007 and 2008 seasons, to study the effect of irrigation water amounts and nitrogen rates, on cucumber yield and the net return from the studied treatments. The experimental field was fertilized by $10 \mathrm{~m}^{3}$ of chicken manure and $15 \mathrm{~kg} \mathrm{P}_{2} \mathrm{O}_{5}$ as superphosphate per feddan under cucumber rows throw soil preparation. Surface drip irrigation system used was consisted of normal polyethylene pipes of $16 \mathrm{~mm}$ diameter as laterals with line dripper of $4.0 \mathrm{~L} / \mathrm{h}$ at $50 \mathrm{~cm}$ apart. The laterals were located $150 \mathrm{~cm}$ apart, one lateral for each plant row. The EC of irrigation water was $1.1 \mathrm{dSm}^{-1}$. Some physical and chemical properties of the experimental soils were determined according to the methods described by Page et al. (1984) and presented in Table 1.

Table (1): Some physical and chemical properties of the experimental soils.

\begin{tabular}{|l|c|c|c|c|c|c|c|c|c|}
\hline Seasons & $\begin{array}{c}\text { Sand } \\
\%\end{array}$ & $\begin{array}{c}\text { Silt } \\
\%\end{array}$ & $\begin{array}{c}\text { Clay } \\
\%\end{array}$ & Texture & $\begin{array}{c}\text { EC dSm } \\
\text { soil paste }\end{array}$ & $\begin{array}{c}\text { pH } \\
\mathbf{1 : 2 . 5}\end{array}$ & \multicolumn{2}{|c|}{$\begin{array}{c}\text { Available nutrients } \\
\left(\mathbf{m g ~ k g}^{-1} \text { ) }\right.\end{array}$} \\
\hline 2007 & 74.4 & 13.65 & 11.95 & Sandy loam & 3.8 & 7.4 & 28.0 & 7.0 & $\mathbf{~}$ \\
\hline 2008 & 74.5 & 13.70 & 11.80 & Sandy loam & 3.9 & 7.6 & 27.0 & 6.0 & 380 \\
\hline
\end{tabular}


Split plot design was used with four replicates. The main plots were assigned by four irrigation water amounts $(100 \%, 90 \%, 80 \%$ and $70 \%)$ of evapotranspiration (ETc). The sub-plots were randomly assigned by four nitrogen rates ( 0 addition $\left(\mathrm{N}_{0}\right), 50\left(\mathrm{~N}_{1}\right), 100\left(\mathrm{~N}_{2}\right)$ and $150\left(\mathrm{~N}_{3}\right) \mathrm{kg} \mathrm{N}$ fed ${ }^{-1}$ ) as ammonium nitrate $(33.5 \% \mathrm{~N})$ in ten doses. The first dose was added after 15 days from planting, while the later doses were applied on weekly bases. Cucumber seeds (cucumis sativus L. var. Prince) were manually planted in one row in 11 and 18 July in the first and second seasons, respectively. The distance between hills was $50 \mathrm{~cm}$ and two plants/hill. All field practices were done as usually recommended for cucumber cultivation. Harvesting was began after 30 days from planting. Central area of $45 \mathrm{~m}^{2}$ in each plot was kept for determining cucumber yield to eliminate any border effect.

The amount of water applied at each irrigation was measured by flow meter and calculated according to Keller and Karmeli (1974). The crop evapotranspiration (ETc) values of growing months (July, Aug., Sep. and Oct.) were $3.70,5.57,5.37$ and $3.76 \mathrm{~mm} \mathrm{day}^{-1}$. The obtained data were statistically analyzed according to Snedecor and Cochran (1980). Combined analysis conducted for the data of the two growing seasons according to Cochran and Cox (1957).

Quantitative analysis:

The quadratic polynomial equation has been used to describe the cucumber yield response to nitrogen rates, its general form is:

$$
Y=B_{0}+B_{1} X_{i} \pm B_{2} X_{i}{ }_{i}
$$

Where, the term $(Y)$ is the yield corresponding to nutrient rates $X_{i}$, the term $B_{0}$ is the intercept and $B_{1}$ and $B_{2}$ are the linear and quadratic coefficients, respectively. The constraints $B_{0}, B_{1}$ and $B_{2}$ were calculated using the least squares method.

The maximum addition of fertilizer $\left(\mathrm{X}_{\mathrm{m}}\right)$, the maximum yield $\left(\mathrm{Y}_{\mathrm{m}}\right)$, the optimum rate of fertilizer $\left(\mathrm{X}_{\mathrm{opt}}\right)$, the optimum yield $\left(\mathrm{Y}_{\mathrm{opt}}\right)$, the efficiencies of $\mathrm{N}$ rates $\left(N_{0}, N_{1}, N_{2}\right.$ and $\left.N_{3}\right)(e X)$, the average of efficiency $(e \bar{X})$ of the fertilizer application rate $(X)$ along the range from $X=0$ to $X=i$, the efficiency of fertilizer at optimum rate $\left(e X_{o p t}\right)$, the relative efficiency $(E X)$, the efficiency of soil nitrogen $\left(\mathrm{eX}_{\mathrm{s}}\right)$, the soil nitrogen content $\left(\mathrm{X}_{\mathrm{s}}\right)$ and standard error (SE) can be calculated from the following equations, respectively.

$$
\begin{array}{ll}
\text { 1. } X_{m}=-\frac{B_{1}}{2 B_{2}} & \text { Balba (1961). } \\
\text { 2. } Y_{m}=B_{0}-\frac{B_{1}^{2}}{4 B_{2}} & \text { Capurro and Voss (1981). } \\
\text { 3. } X_{o p t}=\frac{P_{r}-B_{1}}{2 B_{2}} & \text { Balba (1964). }
\end{array}
$$


Atia, R. H. et al.

4. $\mathrm{Y}_{\mathrm{opt}}=\mathrm{B}_{0}+\frac{\operatorname{Pr}^{2}-\mathrm{B}_{1}^{2}}{4 \mathrm{~B}_{2}}$ Balba (1964).

Where the $(\operatorname{Pr})=\frac{\text { Price of fertilizer unit }}{\text { Price of one ton of crop }}$

5. $e X=B_{1}+2 B_{2} X_{i} \quad$ Thabet and Balba (1994).

6. $\mathrm{e} \bar{X}=B_{1}+B_{2} X_{i} \ldots$ at $X_{i}=3$ units

Thabet and Balba (1994).

7. $\mathrm{e} \mathrm{X}_{\mathrm{opt}}=\mathrm{B}_{1}+\mathrm{B}_{2} \mathrm{X}_{\mathrm{opt}} \ldots$ at $\mathrm{X}=$ optimum rate,Hassanein and El-Shebiny (2000).

8. $E X=0.1 \sqrt{B_{1}^{2}-4 B_{0} B_{2}} \quad$ Capurro and Voss (1981).

9. $\mathrm{eX}_{\mathrm{s}}=\frac{\mathrm{B}_{0}}{\mathrm{X}_{\mathrm{s}}} \quad$ Thabet and Balba (1994).

10. $\mathrm{X}_{\mathrm{s}}=\frac{-\mathrm{B} \pm \sqrt{\mathrm{B}_{1}^{2}-4 \mathrm{~B}_{0} \mathrm{~B}_{2}}}{2 \mathrm{~B}_{2}} \quad$ at $\mathrm{y}=0$

11. $S E=\sqrt{\frac{(\text { Observed - Calcualted })^{2}}{n-2}}$

12. The contribution of soil $N=\frac{X_{S}}{X_{f}+X_{S}} \times$ calculated yield.

13. The contribution of fertilizer $=\frac{X_{f}}{X_{f}+X_{S}} \times$ calculated yield.

\section{RESULTS AND DISCUSSION}

In the present study, cucumber yields were increased successively and significantly with $\mathrm{N}$ increments. The polynomial quadratic equations were established to express the cucumber response to $\mathrm{N}$ application are presented in Table 2.

Table 2:The polynomial equations expressing yield of cucumber and irrigation water amounts of seasons (2007 and 2008).

\begin{tabular}{|c|c|c|}
\hline Treatments & The polynomial equations & $\mathbf{X}_{\mathbf{s}}$ N unit fed-1 \\
\hline $100 \%$ of ETc & $\mathrm{Y}=11.451+7.839 \mathrm{X}-1.329 \mathrm{X}^{2}$ & 1.212 \\
\hline $90 \%$ of ETc & $\mathrm{Y}=10.761+7.333 \mathrm{X}-1.225 \mathrm{X}^{2}$ & 1.219 \\
\hline $80 \%$ of ETc & $\mathrm{Y}=8.978+6.312 \mathrm{X}-1.082 \mathrm{X}^{2}$ & 1.183 \\
\hline $70 \%$ of ETc & $\mathrm{Y}=7.870+5.315 \mathrm{X}-0.863 \mathrm{X}^{2}$ & 1.234 \\
\hline
\end{tabular}


The experimental and calculated cucumber yield values obtained from the polynomial equations 1-4 are presented in Table 2. The calculated yields closely approximate experimental yield as shown from the values of standard error (SE) of estimates and determination coefficient $\left(R^{2}\right)$. The chi square test showed that the calculated yield values from each equations do not significantly differ from the experimental values for each treatment (Table 3).

Table 3: Observed and calculated cucumber yield (ton fed. ${ }^{-1}$ ) under rates of nitrogen fertilizer and irrigation water amounts of 2007 and 2008 seasons.

\begin{tabular}{|l|c|c|c|c|c|c|c|c|}
\hline \multirow{2}{*}{ Treatments } & \multicolumn{2}{|c|}{$\mathbf{1 0 0}$ of ETc } & \multicolumn{2}{c|}{$\mathbf{9 0 \%}$ of ETc } & \multicolumn{2}{c|}{$\mathbf{8 0 \%}$ of ETc } & \multicolumn{2}{|c|}{$\mathbf{7 0 \%}$ of ETc } \\
\cline { 2 - 9 } & observed & calculated & observed & calculated & observed & calculated & observed & calculated \\
\hline $\mathrm{N}_{0}$ & 11.234 & 11.451 & 10.717 & 10.761 & 9.006 & 8.978 & 8.003 & 7.870 \\
\hline $\mathrm{N}_{1}$ & 18.611 & 17.960 & 17.001 & 16.869 & 14.123 & 14.208 & 11.921 & 12.321 \\
\hline $\mathrm{N}_{2}$ & 21.161 & 21.812 & 20.396 & 20.528 & 17.360 & 17.275 & 15.446 & 15.046 \\
\hline $\mathrm{N}_{3}$ & 23.221 & 23.004 & 21.780 & 21.736 & 18.151 & 18.179 & 15.911 & 16.044 \\
\hline
\end{tabular}

\section{Maximum and optimum $\mathbf{N}$ rates:}

Values of maximum and optimum $N$ rates $\left(X_{m}\right.$ and $\left.X_{o p t}\right)$ for each treatment were calculated and presented in Table 4.

Table 4: The maximum $N$ rate $\left(X_{m}\right)$, optimum $N$ rate $\left(X_{\text {opt }}\right)$, maximum yield $\left(Y_{m}\right)$, optimum yield $\left(Y_{o p t}\right)$ and the returns of cucumber yield under irrigation water amounts.

\begin{tabular}{|c|c|c|c|c|c|c|c|c|c|c|c|}
\hline 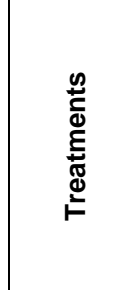 & 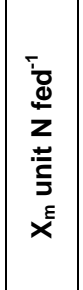 & 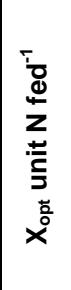 & 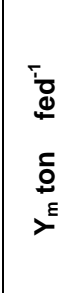 & 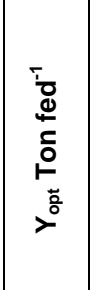 & 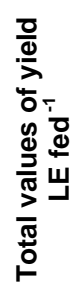 & 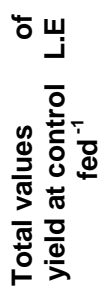 & 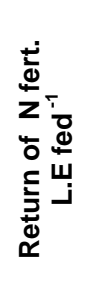 & 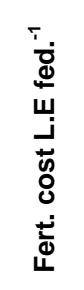 & 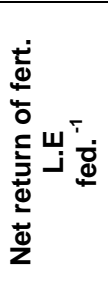 & 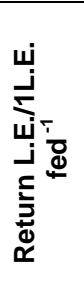 & 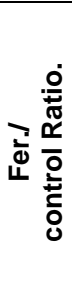 \\
\hline $100 \%$ ETc & 2.949 & 2.878 & 23.010 & 22.975 & 27605 & 13741 & 13864 & 647.6 & 13216 & 20.41 & 1.009 \\
\hline$\%$ ETc & 2.993 & 2.916 & 21.728 & 21.696 & 26074 & 12913 & 13161 & 656.1 & 12505 & 19.06 & 1.019 \\
\hline $80 \%$ ETc & $\mid 2.917$ & 2.829 & 18.175 & 18.140 & 21810 & 10774 & 11036 & 636.5 & 10400 & 16.34 & 1.024 \\
\hline $70 \%$ ETc & 3.079 & 2.969 & 16.043 & 15.998 & 19252 & 9444 & 9808 & 668.0 & 9140 & 13.68 & 1.039 \\
\hline
\end{tabular}

Price of cucumber $=1200$ L.E. $^{-1}$

Fertilizer price $=225{\text { L.E } \text { unit }^{-1}}^{-10}$

Fertilizer unit $=\mathbf{5 0} \mathrm{kg}$

The maximum and optimum $N$ rates $\left(X_{m} \& X_{o p t}\right)$ are the values of fertilizer required to give the maximum and optimum yields $\left(Y_{m} \& Y_{\text {opt }}\right)$. The maximum $\mathrm{N}$ rates $\left(\mathrm{X}_{\mathrm{m}}\right)$ increased from 2.949 unit $\mathrm{N}$ fed $^{-1}$ to 3.079 unit $\mathrm{N}$ fed $^{-1}$ as irrigation water amounts decreased from $100 \%$ of ETc to $70 \%$ of ETc as the mean of the two seasons. The values of the optimum $\mathrm{N}$ rates $\left(\mathrm{X}_{\mathrm{opt}}\right)$ also show the same trend, where it increased from 2.878 unit $\mathrm{N}$ fed $^{-1}$ to 2.969 unit $\mathrm{N} \mathrm{fed}{ }^{-1}$ as irrigation water amounts decreased from $100 \%$ of ETc to $70 \%$ of ETc as the mean of the two seasons. On the other hand, the values of $X_{\text {opt }}$ were less than the values of $X_{m}$, whereas the $X_{o p t}$ were calculated by differentiating $(y)$ in the polynomial equations from $1-4$ with regard to $X$ 
Atia, R. H. et al.

$(\mathrm{dy} / \mathrm{dx})$ and equating with the ratio $(\operatorname{Pr})$ of the price of fertilizer unit and the price of cucumber unit (ton). The increase of $X_{m}$ and $X_{o p t}$ added may be attributed to one or more of the three reasons. The first reason is the effect role of irrigation water amounts on the decomposition of chicken manure. The second is decreasing translocation of the nitrogen to the plant roots, where the main way of the nitrogen translocation is by mass flow with water distribution. The third is the decrease of fertilizer efficiency where the average

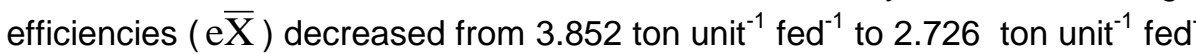
${ }^{1}$ as irrigation water amounts decreased from $100 \%$ of ETc to $70 \%$ of ETc (Table 5). This results are in agreement with those obtained by Simsek et al. (2005).

\section{Maximum and optimum yields:}

Data presented in Table 4 showed that the $Y_{m}$ decreased as irrigation water amounts decreased from $100 \%$ of ETc to $70 \%$ of ETc. The $Y_{m}$ decreased from 23.004 ton fed $^{-1}$ to 16.053 ton fed $^{-1}$ as the average of the two seasons. The highest $Y_{m}$ value (23.010 ton fed ${ }^{-1}$ ) was obtained when 100\% of ETc used. The decrease of $Y_{m}$ was more than $30 \%$ as $70 \%$ of ETc used. This difference between $100 \%$ of ETc and $70 \%$ of ETc values reflect the importance of irrigation water amounts to plant growth and nutrients uptake where increasing irrigation water amounts lead to increase the wet root zone, decrease salts and osmotic effects and increasing fertilizer translocation to the plant roots. These results are encouraged by those reported by Ahmet et al. (2006), Bao Zhong et al.(2006) and Ayotamuno et al. (2007).

As shown in Table 4 the values of $Y_{\text {opt }}$ were less than the values of $Y_{m}$, where the values of $Y_{\text {opt }}$ were obtained by substitution of " $X$ " by corresponding values of $X_{\text {opt }}$ in equations 1-4 found in Table 3. Values of $Y_{\text {opt }}$ show the same trend of $Y_{m}$, where it decreased from 22.975 ton fed ${ }^{-1}$ to 15.998 ton fed $^{-1}$ as ETc decreased from $100 \%$ of ETc to $70 \%$ of ETc (Table 4).

\section{The returns from applied optimum rates}

The returns from applied optimum $\mathrm{N}$ rates are found in Table 4. The total values of the yield decreased from 27605 L.E fed. ${ }^{-1}$ to 19252 L.E fed. ${ }^{-1}$ as irrigation water amount (ETC ) decreased from $100 \%$ of ETc to $70 \%$ of ETc. This decrease was more than $30 \%$ of the returns from applied optimum rates as $100 \%$ of ETc used. Data in Table 4 also, show the returns of $N$ fertilizer and the returns per each Egyptian pound (L.E) spent for each of the applied optimum rate of $\mathrm{N}$ fertilizer. The highest value of L.E/1 L.E was 20.41 when $100 \%$ of ETc applied and the lowest one was 13.68 as $70 \%$ of ETc used. Data presented in Table 4 also, show that fertilizer/control ratio which increased as ETc decreased from $100 \%$ of ETc to $70 \%$ of ETc. This means that the losses of fertilizer increases as irrigation water amount decreases and increase the osmotic pressure in the root zone, as well as, salts which causes less root growth and less utilization of fertilizer. These results are in agreement with those obtained by El- Hady and Wanas (2006) and El-Atawy (2007). 


\section{Efficiencies of nitrogen fertilizer and soil nitrogen:}

The efficiencies of $\mathrm{N}$ rates $\left(\mathrm{N}_{0}, \mathrm{~N}_{1}, \mathrm{~N}_{2}\right.$ and $\left.\mathrm{N}_{3}\right)$, the average efficiencies $(\mathrm{eX})$, the relative efficiency EX, the efficiency of soil nitrogen (eXs) and, the efficiency of optimum $\mathrm{N}$ rate $\left(\mathrm{eX}_{\mathrm{opt}}\right.$ ) are presented in Table 5 .

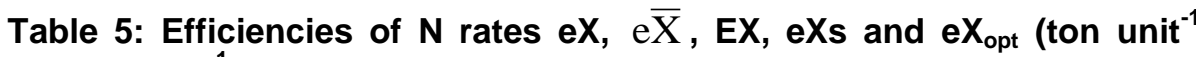
fed $\left.^{1}\right)$ under irrigation water amounts.

\begin{tabular}{|c|c|c|c|c|c|c|c|c|}
\hline \multirow[b]{2}{*}{ Treatments } & \multicolumn{4}{|c|}{ eX (ton unit ${ }^{-1}$ fed $^{-1}$ ) } & & EX & eXs & eXopt \\
\hline & $\mathrm{N}_{0}$ & $\mathbf{N}_{1}$ & $\mathbf{N}_{2}$ & $\mathrm{~N}_{3}$ & \multicolumn{4}{|c|}{ 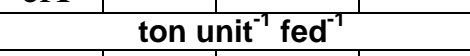 } \\
\hline & 7.839 & 5.181 & 2.523 & -0.135 & 3.852 & 1.106 & 9.448 & 4.014 \\
\hline & 7.333 & 4.883 & 2.433 & -0.017 & 3.658 & 1.032 & 8.828 & 3.761 \\
\hline & 312 & 4.148 & 1.984 & $-0.1 \varepsilon$ & 3.066 & & 7.589 & 3.251 \\
\hline $70 \%$ ETc & 5.315 & 3.589 & 1.863 & 0.137 & 2.726 & 0.744 & 6.378 & 2.753 \\
\hline
\end{tabular}

The efficiencies of $\mathrm{N}$ rates $(\mathrm{eX})$ decreased as $\mathrm{N}$ rates increased from $N_{0}$ to $N_{1}, N_{2}$ and $N_{3}$, respectively under the different irrigation water amounts. It can be stated that the eX values changed from maximum at the beginning at $\mathrm{N}_{0}$ then decreased till it reached zero at the maximum yield and turned to negative at further increments. Values of $\mathrm{e} \overline{\mathrm{X}}$ decreased as irrigation water amounts decreased from $100 \%$ of ETc to $90 \%, 80 \%$ and $70 \%$ of ETc

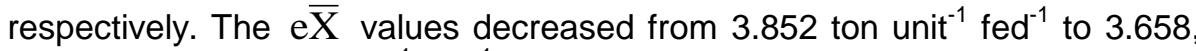
3.066 and 2.726 ton unit $^{-1} \mathrm{fed}^{-1}$ as irrigation water amounts decreased from $100 \%$ of ETc to $90 \%, 80 \%$ and $70 \%$ of ETc, respectively.

The relative efficiency (EX) decreased from 1.106 ton $^{-1}$ unt $^{-1}$ fed $^{-1}$ to $1.032,0.887$ and 0.744 ton unit $^{-1}$ fed $^{-1}$ as irrigation water amounts decreased from $100 \%$ of ETc to $90 \%, 80 \%$ and $70 \%$ of ETc, respectively (Table 5). The soil nitrogen efficiency $(\mathrm{eXs})$ and the efficiency of optimum $\mathrm{N}$ rate $\left(\mathrm{eX}_{\mathrm{opt}}\right)$ showed the same trend of EX.

It is clear from above mentioned results that the different efficiencies of fertilizer (Table 5) decreased as irrigation water amounts decreased. These results reflect the effect of irrigation water amount on plant growth, where its increase increased the surface area per unit root length and enhanced root hair branching with an eventual increase in the uptake of nutrients from the soil and vice versa. The results are in agreement with those obtained by Thabet and Balba (1994), Atia (2005) , Atia et al. (2007) and Atia et al. (2009) who stated that the efficiency of nitrogen fertilizer had decreased with increasing $\mathrm{N}$ fertilizer levels.

\section{Contribution of soil and fertilizer $\mathbf{N}$ to yield:}

In fact, the roots absorb the plant needs of $\mathrm{N}$ from two available sources of $\mathrm{N}$, the soil source and the fertilizer source. Accordingly, the contribution of the soil source in yield would be equal to $\frac{X_{s}}{X_{f}+X_{s}} x$ 
Atia, R. H. et al.

calculated yield, and the contribution of fertilizer source $=\frac{X_{f}}{X_{f}+X_{s}} x$ calculated yield.

The results obtained by using this method are presented in Table 6 .

Table 6:Contribution of soil $\mathbf{N}$ and added fertilizer $\mathrm{N}$ to cucumber yield at different irrigation water amounts as average of two seasons (2007 and 2008).

\begin{tabular}{|c|c|c|c|c|c|c|c|c|}
\hline \multirow[b]{2}{*}{ Treatments } & \multicolumn{2}{|c|}{$100 \%$ of ETc } & \multicolumn{2}{|c|}{$90 \%$ of ETc } & \multicolumn{2}{|c|}{$80 \%$ of ETc } & \multicolumn{2}{|c|}{$70 \%$ of ETc } \\
\hline & $\begin{array}{l}\text { Soil } \mathbf{N} \\
\text { ton fed. }^{-1}\end{array}$ & $\begin{array}{c}\text { Fert. N } \\
\text { ton fed. }{ }^{-1}\end{array}$ & $\begin{array}{l}\text { Soil } \mathrm{N} \\
\text { ton fed. }\end{array}$ & $\begin{array}{l}\text { Fert. N } \\
\text { ton fed. }\end{array}$ & $\begin{array}{c}\text { Soil N } \\
\text { ton fed. }\end{array}$ & $\begin{array}{l}\text { Fert. N } \\
\text { ton fed. }\end{array}$ & $\begin{array}{c}\text { Soil N } \\
\text { ton fed. }^{-1}\end{array}$ & $\begin{array}{l}\text { Fert. } \mathbf{N} \\
\text { ton fed. }^{-1}\end{array}$ \\
\hline $\mathrm{N}_{0}$ & 11.451 & 0.000 & 10.761 & 0.000 & 8.979 & 0.000 & 7.870 & 0.000 \\
\hline $\mathrm{N}_{1}$ & 9.878 & 8.082 & 9.278 & 7.591 & 7.672 & 7.536 & 6.777 & 5.544 \\
\hline $\mathrm{N}_{2}$ & 8.289 & 13.523 & 7.801 & 12.727 & 6.392 & 10.883 & 5.717 & 9.329 \\
\hline $\mathrm{N}_{4}$ & 6.671 & 16.333 & 6.303 & 15.433 & 5.090 & 13.089 & 4.653 & 11.391 \\
\hline
\end{tabular}

Results showed that the contribution of $\mathrm{N}$ fertilizer increased as $\mathrm{N}$ rates increased from $N_{0}$ to $N_{1}, N_{2}$ and $N_{3}$ with the different irrigation water amounts. For example the values of $100 \%$ of ETc increased from 0.0 ton fed ${ }^{-1}$ to $8.082,13.523$ and 16.333 ton fed ${ }^{-1}$, respectively as $N$ rates increased from $N_{0}$ to $\mathrm{N}_{1}, \mathrm{~N}_{2}$ and $\mathrm{N}_{3}$. On contrast, the contribution of soil $\mathrm{N}$ decreased as $\mathrm{N}$ rates increased from $\mathrm{N}_{0}$ to $\mathrm{N}_{1}, \mathrm{~N}_{2}$ and $\mathrm{N}_{3}$, respectively. Other irrigation water amounts $90 \%, 80 \%$ and $70 \%$ of ETc gave the same trend. Thabet and Balba (1994) obtained similar results, where they stated that the contribution of $\mathrm{N}$ fertilizer to the rice grain yields increased with the increase of fertilizer $\mathrm{N}$ application under different levels of tillage, and the contribution of soil $\mathrm{N}$ to the rice grain yields decreased with the increase in the fertilizer $\mathrm{N}$ application under different levels of tillage. The results are in agreement with those obtained by Atia (2005), Atia et al. (2007) and Atia et al. (2009).

Data presented in Table 7 showed that the contribution fraction of $\mathrm{N}$ fertilizer increased as $\mathrm{N}$ rates increased, it increased from 0.00 to $0.45,0.62$ and 0.71 as $\mathrm{N}$ fertilizer increased from $\mathrm{N}_{0}$ to $\mathrm{N}_{1}, \mathrm{~N}_{2}$ and $\mathrm{N}_{3}$ as $100 \%$ of ETc used. The other irrigation water amounts $(90 \%, 80 \%$ and $70 \%$ of ETc) gave the same trend. The contribution fraction of soil $\mathrm{N}$ deceased with increasing $\mathrm{N}$ rates.

Table 7: Contribution fraction of soil $\mathbf{N}$ and added fertilizer to cucumber yield at different irrigation water amount as average of two seasons (2007 and 2008).

\begin{tabular}{|c|c|c|c|c|c|c|c|c|}
\hline \multirow[t]{2}{*}{ Treatments } & \multicolumn{2}{|c|}{$100 \%$ of ETc } & \multicolumn{2}{|c|}{$90 \%$ of ETc } & \multicolumn{2}{|c|}{$80 \%$ of ETc } & \multicolumn{2}{|c|}{$70 \%$ of ETc } \\
\hline & \begin{tabular}{|c|} 
Soil $\mathrm{N}$ \\
ton fed.
\end{tabular} & $\begin{array}{l}\text { Fert .N } \\
\text { ton fed. }^{-1}\end{array}$ & $\begin{array}{c}\text { Soil N } \\
\text { ton fed. }\end{array}$ & $\begin{array}{l}\text { Fert. N } \\
\text { ton fed. }{ }^{-1}\end{array}$ & \begin{tabular}{|c|} 
Soil $\mathbf{N}$ \\
ton fed.
\end{tabular} & $\begin{array}{r}\text { Fert. N } \\
\text { ton fed. }\end{array}$ & $\begin{array}{c}\text { Soil } \mathrm{N} \\
\text { ton fed. }\end{array}$ & $\begin{array}{c}\text { Fert .N } \\
\text { ton fed. }\end{array}$ \\
\hline $\mathrm{N}_{0}$ & 1.00 & 0.00 & 1.00 & 0.00 & 1.00 & 0.00 & 1.00 & 0.00 \\
\hline $\mathrm{N}_{1}$ & 0.55 & 0.45 & 0.55 & 0.45 & 0.54 & 0.46 & 0.55 & 0.45 \\
\hline $\mathrm{N}_{2}$ & 0.38 & 0.62 & 0.38 & 0.62 & 0.37 & 0.63 & 0.38 & 0.62 \\
\hline $\mathrm{N}_{3}$ & 0.29 & 0.71 & 0.29 & 0.71 & 0.28 & 0.72 & 0.29 & 0.71 \\
\hline
\end{tabular}


The values of contribution fraction of soil $\mathrm{N}$ decreased from 1.0 to 0.55 , 0.38 and 0.29 as $N$ rates increased from $N_{0}$ to $N_{1}, N_{2}$ and $N_{3}$, respectively with $100 \%$ of ETc. The same trend was observed as other irrigation water amounts used, where increasing nitrogen fertilizer application led to increase soil available nitrogen from the fertilizer source and causes inhibition of the soil microorganisms and mineralization process and reverse is right.

\section{Conculusion}

It could concluded from calculated equation that the optimum and high quality of cucumber yield achieved by the addition of $144 \mathrm{~kg} \mathrm{~N}^{-1}$ with $100 \%$ of ETC

\section{REFERENCES}

Ahmet, E. S. Sensoy, I. Gedik and K. Kucukyumuk (2006). Irrigation scheduling based on pan evaporation values for cucumber (Cucumis sativa L.) grown under field condition. Agric. Water Manag. ISSN 3774-3780 Vol. 81, No. 1-2, pp: 159-172.

Atia, R. H., H. S. Hamoud and A. S. M. El-Saady (2009). Effect of (Halex-2) biofertilizer inoculation on cowpea yield and mineral fertilization- $\mathrm{N}$ optimization. J. Agric. Sci. Mansoura Univ. 34: 5487- 5494.

Atia, R. H.; R. E. Knany; A. S. M. El-Saady and M. I. Zidan (2007). Sugar beet response to nitrogen forms and rates under different tillage practices expressed by polynomial quadratic equations. Egypt J. Agric. Res. 85 (4): 1127-1139.

Atia, R. H. (2005). A quantitative evaluation of soybean response to nitrogen under sulphur and phosphorus addition. Alex. Sci. Exch. J., 26(4): 355362.

Ayotamuno, J. M., K. Zuofa, O. A. Sunday and B. R. Kogbara (2007). Response of maize and cucumber intercrop to soil moisture control through irrigation and mulching during the dry season in Nigeria. African Journal of Biotechnology Vol. 6 (5) pp: 509-515.

Balba, A. M. (1987).Quantifying plant relationships with nutrients .Alex. Sci Exc. Vol. 8 No. 3 pp:1-22

Balba, A. M. (1964). A quantitative study of cotton response to nitrogen and phosphorus fertilization. J. Soil Sci. U.A.R., 4. (2): 105-117.

Balba, A. M. (1961). Quantitative soil-plant relationship through mathematical and radioactive technique. Alex. J. Agric. Sci., 11: 1098. p: 109.

Bao-Zhong, Y. Jie, K. Yaohu and S. Nishiyama (2006). Response of cucumber to drip irrigation water under a rain shelter. Agric. Water Manag. ISSN 0378-3774 vol. 81, No. 1-2 pp: 145-158.

Capurro, E. and R. Voss (1981). An index of nutrient efficiency and its application to corn yield response application. Agron. J., 73: 128-135.

Cochran, W. G. and G. M. Cox (1957) Experimental Designs $2{ }^{\text {nd }}$ Edit. pp: 611 , John Wley and Sons, Inc. New York. 
Atia, R. H. et al.

El-Atawy, Gh. Sh. (2007). Irrigation and fertilization management under the condition of Kafr El- Sheikh Governorate soil. Ph. D. Thesis, Soil Dept. Fac. of Agriculture, Mansoura Univ., Egypt.

El-Atawy, Gh. Sh. (2010). Potential productivity of cucumber as affected by irrigation water amounts and nitrogen fertilization under drip irrigation at Northwest Delta, Egypt. J. Soil Sci. and Agric. Engineering, Mansoura Univ., Vol. 1 (4): 395-405.

El-Hady, O. A. and Sh. A. Wanas (2006). Water and fertilizer use efficiency by cucumber grown under stress on sandy soil treated with acrylamide hydrogels. Journal of Applied Sciences Research. 2 (12): 1293-1297.

El-Shebiny, G. M. and F. I. M. Bader (1998). Onion yield response to urea and some urea derivatives expressed by polynomial quadratic equations. Alex. Sci. Exch. Vol. 19 No. 4, pp: 571-582.

Hassanein, M. A. and G. M. El-Shebiny (2000). Contribution of bio- and mineral nitrogen fertilization in sugar beet yield. Alex. Sci. Exch., 21(2): 129-143.

Jilani, M. S., A. K. Waseem and M. Kiran (2009). Effect of different levels of NPK on the growth and yield of cucumber (Cucumis sativus) under the plastic tunnel. Agric. Soc. Vol. 5, No. 3: 99-101.

Kadans, J. M. (1979). Encyclopedia of Medical Foods Thoms Pub. Ltd., Willing Borough, North Ampotneshine U. J. pp: 92.

Kellelr, J. and D. Karmeli (1974). Trickle irrigation design parameters. ASAE, 17 (4): 678-684.

Knany, R .E., R. H .Atia, and A. S. M. El-Saady (2005). Effects of different tillage practice nitrogen forms levels on sugar beet yield and juice quality. Alex. Sci. Exch. Vol. 26 No. 3 pp: 217-223.

Page, A. L., R. H. Miller and D. R. Keeney (1984). Methods of soil analysis, Madison, Wisconsin U. S. A. Part 2.

Simsek, M., T. Tonkaz, M. Kacira, N. Cömlekcioglu and Z. Dogan, (2005). The effects of different irrigation regimes on cucumber (Cucumbis sativus L.) yield and yield characteristics under open field conditions. Agric. Water Manag. Vol. 73, Issue 3, pp: 173-190.

Singh, S. S., P. Gupta and A. K. Gupta (2003). Handbook of Agricultural Science kalyani Publishers, New Delhi, India. pp: 184-185.

Snedecor, G. W. and W. G. Cochran, (1980). Statistical methods $7^{\text {th }}$ Edition low State Univ. Press. Ames. lowa, U. S. A.

Thabet A. G. and A. M. Balba (1994). Soil and fertilizer-N efficiencies using wheat grain response equations to $\mathrm{N}$ and tillage. Arid Soil Research and Rehabilitation. 8: 115-124.

Watcharasak, S. and T. Thammasak, (2005). Effect of nitrogen and potassium concentration in fertigation on growth and yield of cucumber. Kamphaengsaen Acad. J., 3: 18-29. 
تأثير كميات مياه الري ومعدلات التسميد النتروجيني علي محصول الخيار والعائد

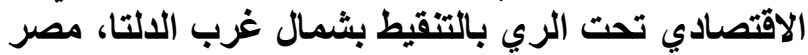

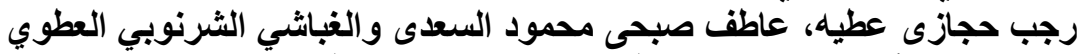

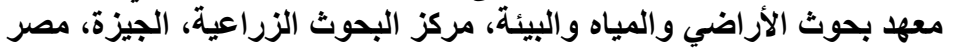

أقيمت تجربتان حقليتان خلال موسمي الزراعة 2007 و2008 بمنطقة وادي النطرون

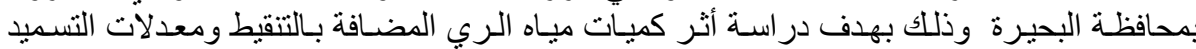

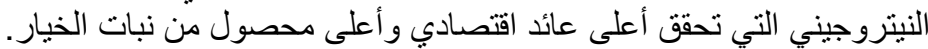

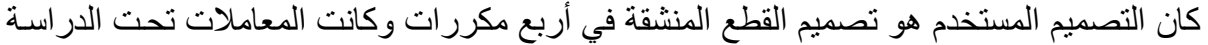

أولا: القطع الرئيسية وكانت لمعاملات الري كما يلي:

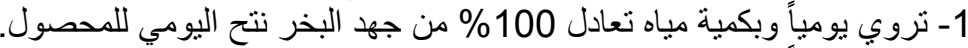

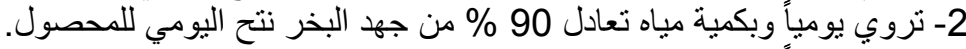

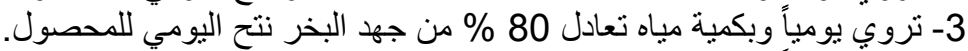
4- تروي يومياً وبكمية مياه تعادل 70 \% م من جهد البخر نتح اليومي للمحصول.

ثانيا:كاتت القطع المنشقة لأربعة مستويات نيتروجينية هي: صفر ، 50، 100 و 150 كجم نيتروجين للفدان،

ونم إضافة 10 م³ سماد دواجن + 15 كجم سوبر فوسفات للفدان في خطوط الخيار قبل

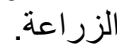

وقد استخدمت أربع معادلات من معادلات الارجة الثانية للحصول على النتائج التالية:

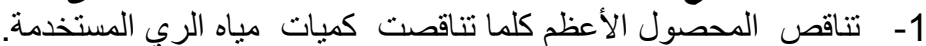

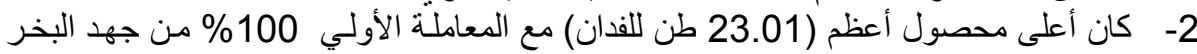

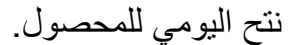

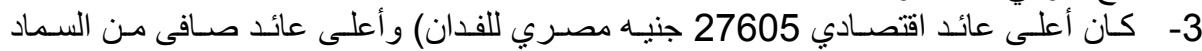

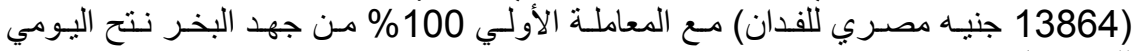

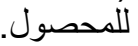

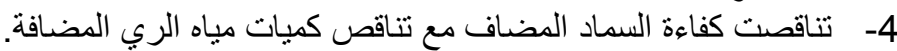

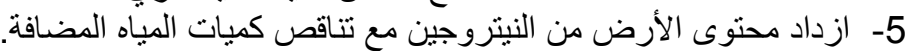

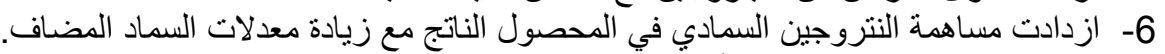

7- تناقصت مساهمة النتروجين الأرضي في المحصول النحول الناتج مع زيادة معدلات السماد المضاف.

كلية الزراعة - جامعة المنصورة كلية الزراعة - جامعة كفر الثيخ

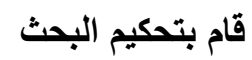

أ.د / سامى عبد الحميد حماد أ.د / صابر عبده جاهين 